\title{
SETE AULAS DE VIGOTSKI
}

\author{
Itale Luciane Cericato ${ }^{1}$; https://orcid.org/0000-0003-1163-3551
}

A obra contém sete aulas proferidas por Lev Vigotski, pensador soviético cujos estudos possuem forte influência no Brasil nas áreas da educação e da psicologia. A tradução foi realizada pelas organizadoras e por Claudia da Costa Guimarães Santana. Possui uma apresentação; o texto "O bom, o mau e o feio", ambos escritos pelas organizadoras; o capítulo "Fundamentos da pedologia de L.S. Vigotski”, que contém as sete aulas anunciadas no título, e, finalmente, um capítulo denominado "As falsas ideias de L.S. Vigotski na pedologia”, de Eva Izrailevna Rudniova.

$\mathrm{Na}$ apresentação, Prestes e Tunes destacam que os textos são inéditos em português, fato que enaltece a relevância da obra. O trabalho de tradução dos textos de Vigotski do russo para o português tem sido, aliás, alvo da dedicação de Prestes, que já evidenciou, em trabalhos anteriores (Prestes, 2012), problemáticas decorrentes de equívocos que comprometeram a compreensão das ideias originais propostas pelo autor. Ao defender um criterioso trabalho de tradução, que permita ao leitor brasileiro o acesso ao pensamento fidedigno de Vigotski, Prestes realiza extensa pesquisa biográfica e bibliográfica, entrevistando familiares de Vigotski, acessando materiais escritos na língua russa e comparando edições das obras publicadas em diferentes línguas.

Em "O bom, o mau e o feio", são descritos fatos ocorridos na União Soviética na década de 1930, na era de Stalin, época em que vigorava um regime que "perseguia e matava" (p. 7). Para as autoras, "há, pois, fundamentos para a conjectura partilhada entre estudiosos da obra de L.S. Vigotski de que se ele não tivesse falecido de tuberculose na madrugada de 11 de junho de 1934, seria, sem dúvida, mais um nome na enorme lista de mortos pelas mãos de Stalin no grande expurgo que ocorreu nos últimos anos da década de $1930 "$ (p. 8). Além de apresentarem dados sobre as dificuldades de Stalin para compreender a dialética proposta pelo pensamento marxista e sobre os comportamentos hostis e de perseguição em relação a adeptos dessa forma de pensar, as organizadoras consideram o posicionamento de Eva Izrailevna Rudniova em relação às ideias de Vigotski uma crítica encomendada, num texto que apresenta "inúmeras incoerências lógicas, contradições e distorções das ideias de Vigotski. Vê-se que o rigor, próprio de um texto acadêmico, está completamente ausente. (...) Custa-nos acreditar também que foi escrito por uma acadêmica com mais de cem publicações científicas. (...) Será que foi, de fato, escrito por Rudniova?", questionam (pp. 12-13). O capítulo é encerrado com considerações sobre o aspecto didático e o rigor científico e metodológico apresentado em cada uma das sete aulas. "Cada aula tem, no início, a enunciação de seus objetivos, antecedida, da segunda em diante, de uma síntese do que foi tratado na aula anterior, procurando-se mostrar como segue o raciocínio. No decorrer de cada aula, são apresentados muitos exemplos e contraexemplos extraídos tanto do cotidiano quanto, principalmente, de estudos de outros pesquisadores" (p. 14).

Na primeira aula, Vigotski apresenta o desenvolvimento da criança como objeto de estudo da pedologia e evidencia que esse desenvolvimento decorre de uma organização complexa e cíclica no tempo, envolvendo uma combinação de fatores: "O ritmo do desenvolvimento, a sequência das etapas que a criança percorre, os prazos que são necessários para que ela passe cada etapa não coincidem com o ritmo do tempo, não coincidem com a contagem cronológica do tempo" (p. 18).

Na segunda aula, é abordado o método da pedologia, o qual apresenta três características principais: estudo da unidade - e não de elementos - do desenvolvimento infantil, ou seja, "a unidade é definida pelo fato de que é a parte que contém, mesmo que de forma embrionária, todas as características fundamentais próprias do todo" (p. 40); estudo dos fenômenos em seu processo de mudança, isto é, ao longo do processo de desenvolvimento, e não como sintomas isolados típicos de determinadas idades; e estudo do percurso do desenvolvimento da criança, evidenciando a trajetória dessa construção.

A terceira aula trata da relação entre a hereditariedade e o meio na pedologia a partir de exemplos de pesquisas com gêmeos uni e bivitelinos. Esclarecendo

1 Universidade Federal de São Paulo - UNIFESP - São Paulo - SP - Brasil; italecericato@hotmail.com 
que "não interessa ao pedólogo as características puramente hereditárias, que independem do meio, mas aquelas cujo desenvolvimento sofre influência conjunta do meio e da hereditariedade" (p. 58), Vigotski afirma que "a pedologia estuda o papel da hereditariedade no desenvolvimento e, por isso, focaliza características híbridas, instáveis, e que se submetem à alteração no processo de desenvolvimento da criança" (p. 59).

A quarta aula não é um texto inédito em português porque já foi traduzido, em 2010, na revista Psicologia, da Universidade de São Paulo, por Márcia Pileggi Vinha. Discute o papel do meio no desenvolvimento da criança e apresenta o conceito de vivência, que permite a cada indivíduo internalizar as experiências proporcionadas pelo social de modo particular. Para Vigotski, "o homem é um ser social e, fora da relação com a sociedade, jamais desenvolveria as qualidades, as características que são resultado do desenvolvimento metódico de toda a humanidade" (p. 90).

$\mathrm{Na}$ quinta aula, Vigotski discorre sobre as leis gerais do desenvolvimento psicológico da criança apresentando as peculiaridades que as compõem. $\mathrm{O}$ processo de diferenciação da consciência é evidenciado nas etapas de sua construção.

A sexta aula trata das leis gerais do desenvolvimento físico abordado em sua íntima relação com o desenvolvimento psicológico. $\mathrm{O}$ autor mostra que o desenvolvimento físico decorre de um processo complexo do qual participam diferentes sistemas orgânicos regidos por suas especificidades, havendo, contudo, uma unidade que relaciona cada um desses sistemas ao desempenho das funções do cérebro e ao desenvolvimento psicológico.

A sétima aula aborda as leis do desenvolvimento do sistema nervoso, explicando como "funções que eram executadas por centros ou áreas inferiores do cérebro nos estágios iniciais de desenvolvimento começam, no decorrer deste, a ser executadas por centros superiores" (p. 130) e vice-versa, ilustrando com exemplos de situações normais e patológicas na infância e na idade adulta.

Em "As falsas ideias de L.S. Vigotski na pedologia”, de Eva Izrailevna Rudniova, como já anunciado, o leitor encontrará um texto construído em torno de críticas que objetivam deturpar os conceitos da obra de Vigotski, desqualificando seu trabalho. As críticas fazem uso de uma linguagem pejorativa: "teoria estapafúrdia, anticientífica" (p. 164) e "essa teoriazinha muito nociva, ligada à 'teoria' da predestinação da criança pelos fatores biológicos e sociais, desestimula e desarma o professor: em vez de lhe indicar os meios mais efetivos de educação e instrução" (p. 165). O método de trabalho adotado por Vigotski é também questionado: "é preciso levar em consideração que o trabalho experimental nas investigações de Vigotski, em geral, ocupa um lugar bastante limitado" (p. 168), assim como seus fundamentos epistemológicos: "Vigotski não compreende o estudo marxista-leninista do meio e ignora o papel do homem na transformação do meio" (p. 175). Ora, qualquer leitor atento constata que tais críticas são infundadas e superficiais porque o rigor do trabalho metodológico de Vigotski se mostra em textos bem exemplificados por experimentos detalhadamente construídos, além de sua obra ser permeada de afirmativas que mostram o papel das mediações realizadas pela escola como fundamentais na constituição do ser humano. De todo modo, a leitura do capítulo não deixa de ser importante, sobretudo para suscitar reflexões a respeito do contexto de pós-verdade em que vivemos e sobre os ataques sofridos à educação e aos professores.

Por fim, a obra é leitura necessária para estudantes e profissionais das áreas de educação e psicologia interessados não apenas no aprofundamento histórico e conceitual dos postulados vigotskianos, mas também no desenvolvimento infantil de modo geral.

\section{Referências}

Prestes, Z. (2012). Quando não é quase a mesma coisa: traduc̃ôes de Lev Semionovitch Vigotski no Brasil. Campinas: Autores Associados.

Vigotski, L.S. (2010). Quarta aula: a questão do meio na pedologia. Psicologia USP, 21 (4), 681-701.

Vigotski, L.S. (2018). Sete aulas de Vigotski sobre os fundamentos da pedologia (1a. ed.). (Z. Prestes \& E. Tunes, Orgs. e Trad.; C.C.G. Santana, Trad.). Rio de Janeiro: E-papers.

Recebido em: 19 de julho de 2019 Aprovado em: 05 de julho de 2020 